\title{
The Gods die in museums
}

\author{
Jaime DELGADO RUBIO \\ Faculty of Political and Social Sciences, UNAM \\ jaime.delgado@politicas.unam.mx
}

\section{ABSTRACT}

Recently, Johannes Neurath's book, titled Subdue the gods, doubt the images (2020) was published, which, among other things, warns that, in the archaeological museums of Mexico, including the National Institute of Anthropology and History of Mexico City, there has been an "ontological mistreatment" of the sacred images of the pre-Hispanic era through their removal from their original locations and indistinct placement in large and cold rooms packed with monoliths, without any consideration for the fact that some were - and continue to be - images bestowed with power and influence by many communities today.

\section{KEYWORDS}

Ontologies; Museums; Gods; rituals; visitors

AP: Online Journal in Public Archaeology - Volume 11 - ISSN: 2171-6315

Delgado Rubio, J. 2021. The Gods die in museums. AP: Online Journal in Public Archaeology 11, s1-s14.

DOI: 10.23914/ap.v11i0.308

Received: 29/04/2021 :: Accepted: 27/10/2021 


\section{s2 :: AP Journal v.11 :: SHORT ARTICLE}

As an archaeologist, I am already aware that many of our classificatory methods are undertaken regardless of the absurdity that they may give rise to in the short and medium term: for example, when identifying a pre-Hispanic burial, we almost instinctively devote ourselves to drawing, recording and removing it from its place of origin by wrapping each of its parts in aluminum foil. The operation is considered to have been completed successfully once we have assigned a number to the burial and then placed it in a basement for time immemorial, while the gathered bones slowly turn to dust.

The problem with this "procedure" is that, except in extraordinary cases (in which the specimen exhibits unique pathologies, deformation practices, regenerations, etc.), it should be considered absurd to remove a human skeleton to then simply condemn it to oblivion in a cellar, while at the same time disregarding the fact that, at the time of interment, the body was the subject of sacred treatment, that it was mourned, anointed and consecrated to the deities, in a space that was also sacred. Therefore, we should consider being more professionally respectful and think about on-site sampling and recording solutions, as is done in the United States with NAGPRA.

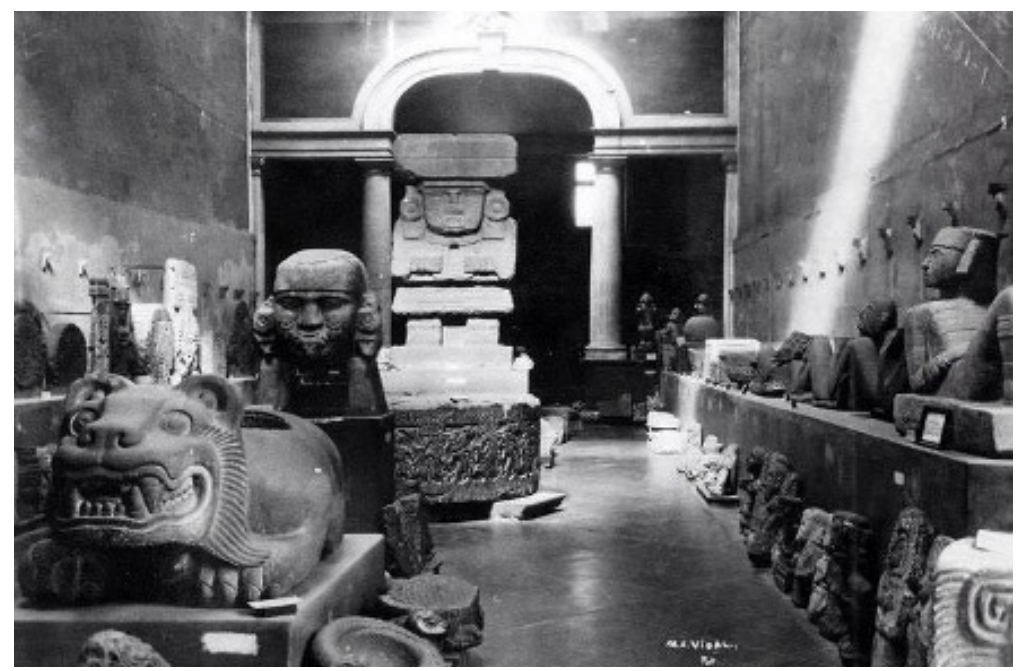

Fig. 1: The museum death of deities occurs when they are denied their influence. Photograph from the official website of INAH.gob.mx

\footnotetext{
1 Since 1990, federal law has provided for the repatriation and disposition of certain human remains, funeral objects, sacred objects, and objects of cultural heritage of Native Americans. In enacting NAGPRA, Congress recognized that human remains of any ancestry "must be treated at all times with dignity and respect." Congress also recognized that human remains and other cultural items removed from federal or tribal lands belong, first of all, to direct descendants, Native American tribes, and Native Hawaiian organizations. With this law, Congress sought to foster an ongoing dialogue between museums and Native American tribes and Native Hawaiian organizations and promote greater understanding among groups while recognizing the important role museums play in society by preserving the past (NAGPRA: 2021)
} 
In this sense, I agree with Hamilakis that we are a strange species of professionals who have been educated in a visual sensory world, which favors "evidence" to the detriment of that which cannot be seen, touched, quantified and demonstrated. We are victims of what he terms an "epistemology of evidence" (2015: 20). Blanca Cárdenas's remark reflects a similar way of thinking, when she reminds us that, although it is not evident, the ritualism surrounding images and figures of gods undertaken by the communities existed - and in many cases continues to exist - largely in order to invoke respect for their capabilities and powers, and this fact alone should force us to imagine other ways of exhibiting them (Cárdenas 2021).

Now, in museographic terms, we must point out that once these deities pass through the filter of the museum/academia, they become the subject of a conversion that transforms them from a corporeal ritual image to a patrimonial object guarded by the State, all while passing through a series of crossed intellectual operations undertaken through the lens of the hierarchical, linear and chronological thinking of the modern academic, a phenomenon that we will analyze below.

The result of these actions is what we have termed "museum death", with the creation of large and cold galleries of monoliths duly sanitized and dispossessed of all their capacities and symbolic powers, separated from their worshippers, their shamans and their communities of origin. In return, these monoliths are given a showcase and special lighting, along with an abstract card that indicates their origin, temporality, shape and type.

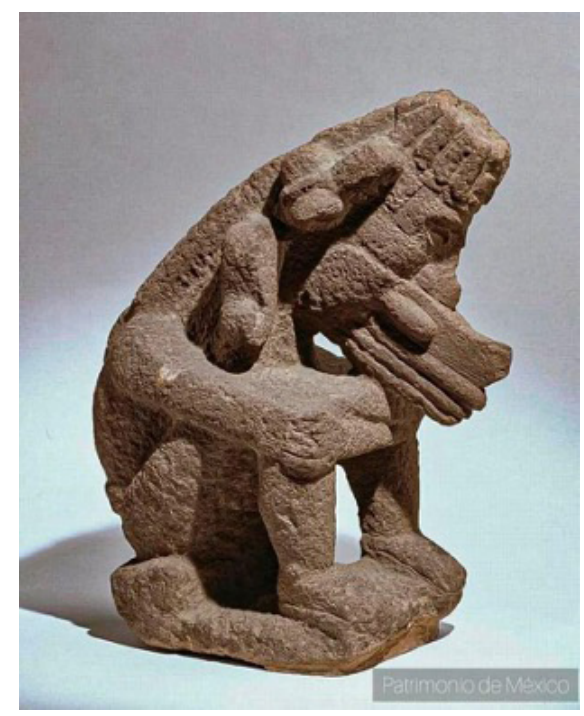

Fig. 2: Sacred images separated from their abilities, influence, worshippers and shamans. Photograph courtesy of the Philadelphia Museum of Art. 


\section{s4 :: AP Journal v.11 :: SHORT ARTICLE}

A case that comes to mind is the teponaztli of Tepoztlán, Morelos State, which was signified by the local community as a living creature, corporeal and capable of action, which, according to the tradition of the town, dates back to pre-Hispanic times. Its discovery was - and continues to be - considered key to maintaining the good health of the current Tepoztec communities. However, this little "wooden god" was transferred by government decision to the National Institute of Anthropology and History of Mexico City as heritage, with the authorities of the National Institute of Anthropology and History providing a replica to the town of Tepoztlán in return.

In the Tepozteca tradition, it is said that this replica tried to flee at dawn to meet the original teponaztli, which is why its front legs have been cut off, which attests to the psychic powers that the local inhabitants attribute to these objects.

The same occurs with the objects of the offerings, which, according to the available ethnographic and ethnohistorical references, not only represented the gods, but were also key in attempts to contain the deities and the forces of the cosmos. To better illustrate these cases, we want to cite the work of López Austin, who tells us that during the Mexica New Fire Ceremony, the indigenous people used to remain in a perpetual state of anguish and expectancy, looking towards the Cerro Huizachtepetl, and awaiting the arrival of the new sun, "warning that, if it did not rise, many grinding implements, such as metates and molcajetes, would come to life and reveal themselves to their owners" (personal communication, during an interview at IIA-UNAM 2014).

Another example comes from Preus's ethnographic work among the Huichol and Coras, where the Huichol pilgrims transform themselves into their own ancestors embodied in objects such as bowls (women) and arrows (men): this is not a simple metaphor, but rather a form of presentification. In this same ritual pilgrimage, the Huichols ask the gods to sit down and rest, offering them chairs, mats or beds, since they believe that it does not bode well for anybody if the gods move around too much (1998).

He warns that these precautions are necessary, since there is always the risk that fire will spread from the campfire, "or the gods will come out of their gourds or beds, and that the statues will come to life and fly out to attack people" (Johannes 2020, citing Preus).

On the other hand, in Teotihuacan, Von Winning pointed out the existence of some trees painted on the "Mural of the Tepantitla palace" (located east of the ceremonial civic center of Teotihuacan), where small characters can be seen living inside and among the roots, probably as a symbol of the soul of the tree or its psychic abilities (1987: 567).

Finally, we must not forget the "medical" practices known as "air games" in the present-day town of Tlayacapan, Morelos State, in which a small group of female 
healer-shamans perform activities of "cleansing the spirit and evil eye" using a series of figures that, through ritual, come to life and ask the mountain gods to accept the bad air of the patient in exchange for food (Granados 2009).

These examples are enough to establish that not only the gods themselves, but also associated objects, could be key in complex negotiations with beings from other worlds, coming to life and having a will of their own, and even becoming deities themselves.

On the other hand, and returning to the subject of the theft of these deities as a result of archaeological exploration, we must mention that, on some occasions, the custody and safeguarding of these pieces by the Mexican state is fully justified, due to the endangerment of such objects' physical integrity, but, on others, it is a procedural expropriation protected by the academic tradition "because it has always been this way", while at other times still, it has been the product of the personal whims of politicians or officials of each government in turn.

Such was the sadly famous case of the monolith known as "Tláloc", stolen from the Coatlinchán community, State of Mexico, to be placed next to the National Institute of Anthropology and History in Mexico City. In this regard, we must emphasize that this deity had remained semi-buried since pre-Hispanic times, and up to its removal, the local community of Coatlinchán used to offer it corn, flowers and seeds of crops from the previous year to ask for rain or to give thanks for the previous year's harvest.

Removing Tláloc or Chalchitlicue from that community can be considered a form of the above-mentioned mistreatment, and essentially a form of looting; this time internal, legal and on behalf of the nation, but with the same victims as always: the community (Delgado 2021b).

Given this, it seems pertinent to ask ourselves: Would a visitor interested in the pre-Hispanic history of Mexico prefer to see this monument in its place of origin with the local cults, or would they prefer to continue seeing it alongside an avenue beside a parking lot?

A comparable case occurred in the small community of Eleusina in Greece with the sculpture of the goddess Eleusis, a Greek deity rediscovered in the late $17^{\text {th }}$ century by the local community, and the subject of agricultural rituals. Hamilakis describes how offerings of animal excrement, symbolizing agricultural manure, were made to this semi-buried sculpture. It did not take long for such a practice to scandalize the academic community of the $20^{\text {th }}$ century, with conservators declaring that the sculpture was at risk, an argument that was used to justify its transferal to National Archaeological Museum in Athens, where it can be seen today alongside hundreds of other perfectly clean monoliths, but dispossessed of all its sacred ties (2015: 59). 


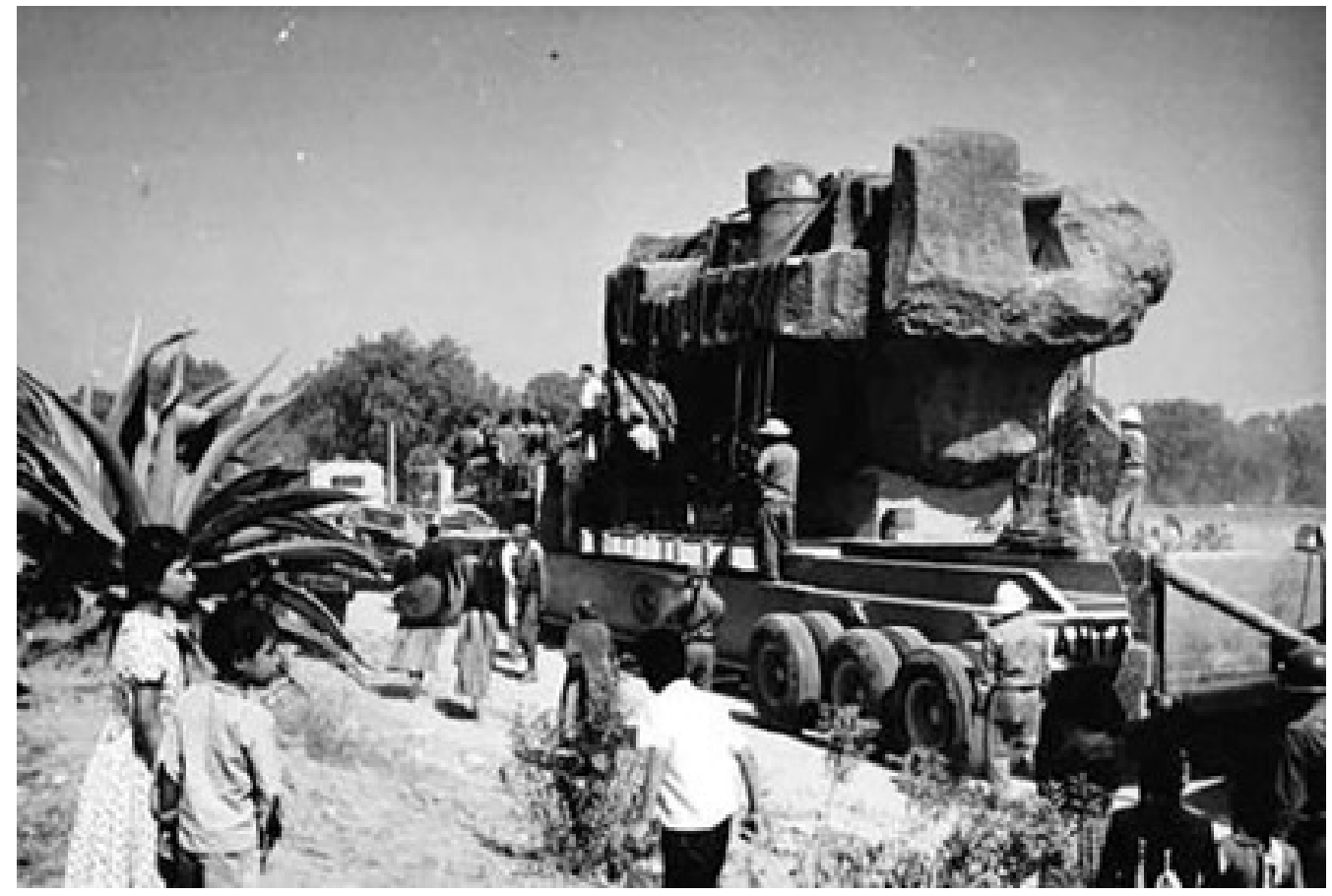

Fig. 3: Relocation of the monolith known as "Tlaloc" to the National Institute of Anthropology and History, a televised event. From https://www.maspormas.com/ciudad/ tlaloc-en-el-museo-de-antropologia/

\section{The passive worshipper and the proactive worshipper}

For some authors, the problem we describe here is not procedural, but rather reveals a structural collision between two different ontologies: the community versus the academic-institutional, a description I generally agree with. But, to further develop this argument, I want to start by saying that an initial difference is the way in which we perceive the cosmos. For many contemporary scholars, the Mesoamerican cosmos is very similar to the Greek cosmos, that is, a great family of gods plagued by personal tragedies, but with rules that they themselves abide by and whose principles they respect to maintain order (Alsina 1991).

These scholars celebrate an ordered, dual and complementary cosmos, which is why they conceive of the worshipper as passive, reverential and minuscule in relation to their gods (in a conception also similar to that of the Catholic faith). When thinking about this type of worshipper, it is perhaps the case that the academic or museum designer conceives worshippers as static and undifferentiated entities. 
Running counter to this is another current, headed by Johannes Neurath, to which I ascribe myself, which postulates that the Mesoamerican cosmos does not conform to this order, but is rather an unstable, uncertain cosmos, full of ruptures and with forces that threaten to break out of control and affect the communities. For this reason, Neurath describes a proactive believer who has to use rites, objects and practices to contain, condense and control these forces (2020). In this case, the believers are proactive worshippers, often represented by the figure of the shaman.

As an example of this proactivity, we want to cite the research of Leopoldo Trejo (2015) with the healers of the southern Huasteca, in the Mexican state of San Luis Potosí, who cut effigies out of paper to offer to the different gods, who are hungry and desire to take the bodies of humans. These healers are key to alleviating the anxiety of the gods.

Another example comes from Teotihuacan, where a small community museum can be observed attached to a restaurant located just behind the Pyramid of the Moon, and managed by Mrs Ema Ortega, who often places a series of offerings on the floor, intended to correct or restore the forces and energies recklessly released by all the archaeologists who have broken into sacred places within the archaeological site, without even realizing their "insolence".

Finally, Fujigaki (2015) points out that such rituals are not always celebratory, but may also be intended to question the deities themselves, and can even annul or ritually kill them, a fact possibly attested to by the marble sculptures broken into hundreds of pieces in the palace complex of Xalla Teotihuacan (López et al., 2004).

\section{Our ritual syntheses}

Another possible explanation for the mistreatment that is inherent within our academic/classificatory system is our categories of form-function analysis that we usually use to "identify" Mesoamerican deities, which are clearly reductionist, as pointed out by Neurath (ibidem).

The "naturalists", represented by scholars who reduce the ritual action of a deity to a simple association with some element of nature, for example, associate a mask with fangs before its eyes with the god of water, a hunched old man with the god of fire, a bird's beak with the god of wind, a woman with corncobs with the goddess of corn, and so on.

With what has been stated so far, we need to ask ourselves an important question: What is the underlying explanation for the academic or museum designer's reluctance to accept the ethnographic approach to deities, and incorporating this 


\section{s8 :: AP Journal v.11 :: SHORT ARTICLE}

into the museological process? To try to give an answer, we start from the premise that, at the ontological level, our common sense has been colonized by the modernity of the West, which is underscored by the idea of a linear, chronological and historical time. We presume ourselves to be scientists, and we do not believe in ritual or religious magical thinking, because we believe that each community of believers ended with its own era.

However, Mesoamerican peoples and communities believed that time was a circle, where the same spirit would continuously start new cycles. According to this concept, the dead went through different stages, and faced numerous challenges in the hope of transcending and returning in a new manifestation (López Austin personal communication 2018).

Within this cycle there was also a mythical time, very remote, in a "time before time". Here, Mircea Eliade tells us that Mesoamerican calendars tried to establish dates for the performance of rituals, festivals and ceremonies that would allow us to recreate the times of the beginning or end of a cycle, sometimes related to the formation of the social group (Eliade 2009).

But approximately three centuries ago, Western civilization broke with this idea, and a social order appeared on the scene that wanted to believe itself to be the creator of history, and with this, the conception of time underwent a transcendental change, since the belief in a linked linear time was imposed, along with the notion of indefinite progress.

This idea was reinforced by the appearance of monotheism and the Bible, in which we observe a linear history that begins at the moment when God makes a pact with the Israelites to seek the Promised Land, in which material and earthly time will never return.

Then an event occurred that affected our common sense and evolutionism, with Charles Darwin and his famous Origin of Species postulating that humanity as we know it arose on the planet through chance, adaptation and survival, as opposed to by means of a metaphysical force or will of an omnipotent being, as had been believed up until that point. In this same sense, Marxism also took up Darwin's linear idea, pointing to religious rituals as "the opium of the masses" and promoting humanity's conquest of nature through work, technique and technology.

Perhaps these are the seeds of our secular scientific thinking, which lead us to disqualify or folklorize any form of ritualism towards the gods, symbolism and cyclical beliefs of transcendence. 


\section{Conclusions}

After what we discussed so far, a clarification becomes necessary: I am not ignoring the role of the Mexican government as a custodian and guarantor of these vestiges, or the public and social usefulness established by law, and even less so the creation of institutions that study, showcase and safeguard pieces.

What I am saying is that the policy of removing and gathering archeological objects is an obviously neo-colonialist concept that, as before, does not recognize the cultural plurality of the country and ignores the right of communities to be consulted before such actions, as conferred by the Political Constitution of the United Mexican States and Convention 169 of the International Labour Organization:

IX. Consult indigenous peoples' opinion and recommendations while preparing the National Development Plan, the State plans and the local plans and, if appropriate, incorporate their recommendations and proposals. (Political Constitution of the United Mexican States 2020: Article 2)

Additionally, Article 4 mandates the Mexican government to recognize the cultural plurality of the nation and its right of cultural expression:

Every person has cultural rights, has the right of access to culture and the right to enjoy state cultural services. The State shall provide the means to spread and develop culture, taking into account the cultural diversity of our country and respecting creative freedom. The law shall provide instruments that guarantee access and participation of any cultural expression. (Ibidem: Article 4)

For this reason, and to address the arguments that could be used against these mandates, I want to point out that nowhere in the Constitution or in federal and state laws regarding monuments and archeological sites is it mentioned that the Mexican government has the right to relocate or gather pieces in Mexico City or state capitals without previously consulting the peoples and communities concerned.

However, is a strategic return of a few pieces to their communities of origin possible, as a symbol of a new era in the relationship between the National Institute of Anthropology and History and civil society?

Not only is the answer affirmative, but it also has already been done. Therefore, I will below present three cases that happened from 2020 onward, which can be taken as signs of changes in our way of maintaining and understanding archeological museums: 


\section{s10 :: AP Journal v.11 :: SHORT ARTICLE}

CASE 1.- The National Institute of Anthropology and History returns pre-Hispanic original pieces to the bottom of the Nevado de Toluca lake.

2020: 52 ritual objects made of copal (a type of resin) that had remained under scientific investigation for more than a decade were put returned to the site where they were discovered in 2007 by experts from the National Institute of Anthropology and History: at the bottom of the Luna lake, inside the crater of the Nevado de Toluca, more than 4,000 meters above sea level.

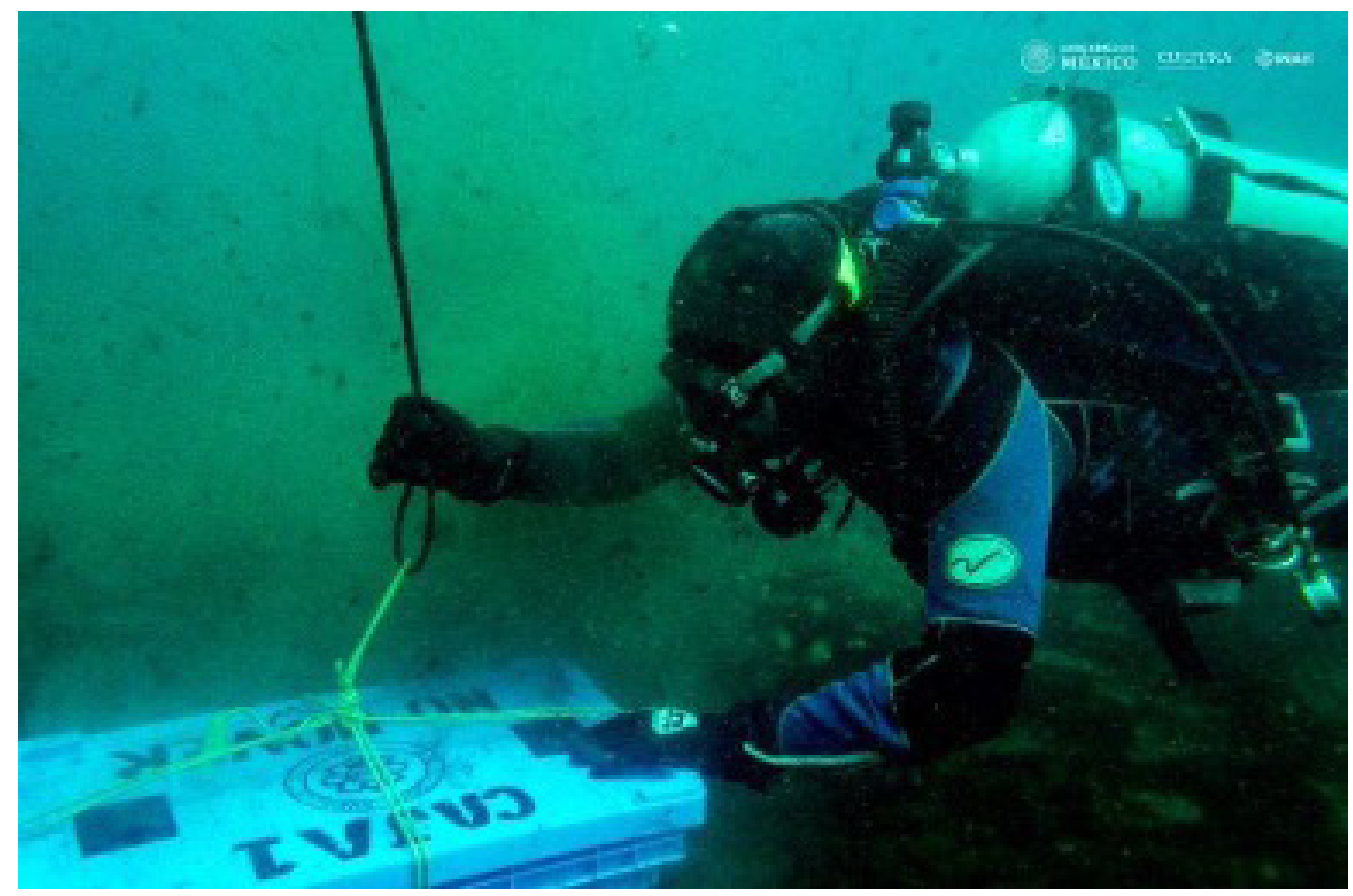

Fig. 4: Returning sacred artifacts to the bottom of Luna lake. Photograph from the official website INAH.gob.

From pre-Hispanic times, the present-day Nevado de Toluca National Park, with its 53,590 hectares, has been a sacred place seen as a deity that gifts water and endows the soil with fertility. An idea that, as ethnographic study has demonstrated, persists in the beliefs of many indigenous communities, who see the mountains as places that provide food, water and abundance.

In addition, small archeological sites have been discovered on the sides of the crater as well as all around the volcano, which may have been "altars" where people would stop for a moment on their way to the lakes, which they would perhaps visit to ask or thank for a good harvest. 
According to the National Institute of Anthropology and History, Mario Castañeda Rojas, director of the National Park, trusts that the same people who petitioned for the return of the pieces will be the first to ensure that they are protected, even though the institute urges tourists to research the specificities of the protected natural area before any visit: these include recommendations about the altitude and environmental conditions, as well as the rules issued by the National Commission on Protected Natural Areas to protect this precious heritage site (INAH 2020a).

CASE 2.- Fossil material from a glyptodon is returned to its place of origin in Puebla

2021: Fossil material from a glyptodon, a giant species of armadillo, was found in 2017 in the Analco neighborhood of Santiago Tenango and, after being extracted by researchers Zaid Lagunas and Sergio Suárez in 2018, was secured, reconstructed and studied in the National Institute of Anthropology and History annex of Puebla, finally being returned last year to its neighborhood of origin, Analco.

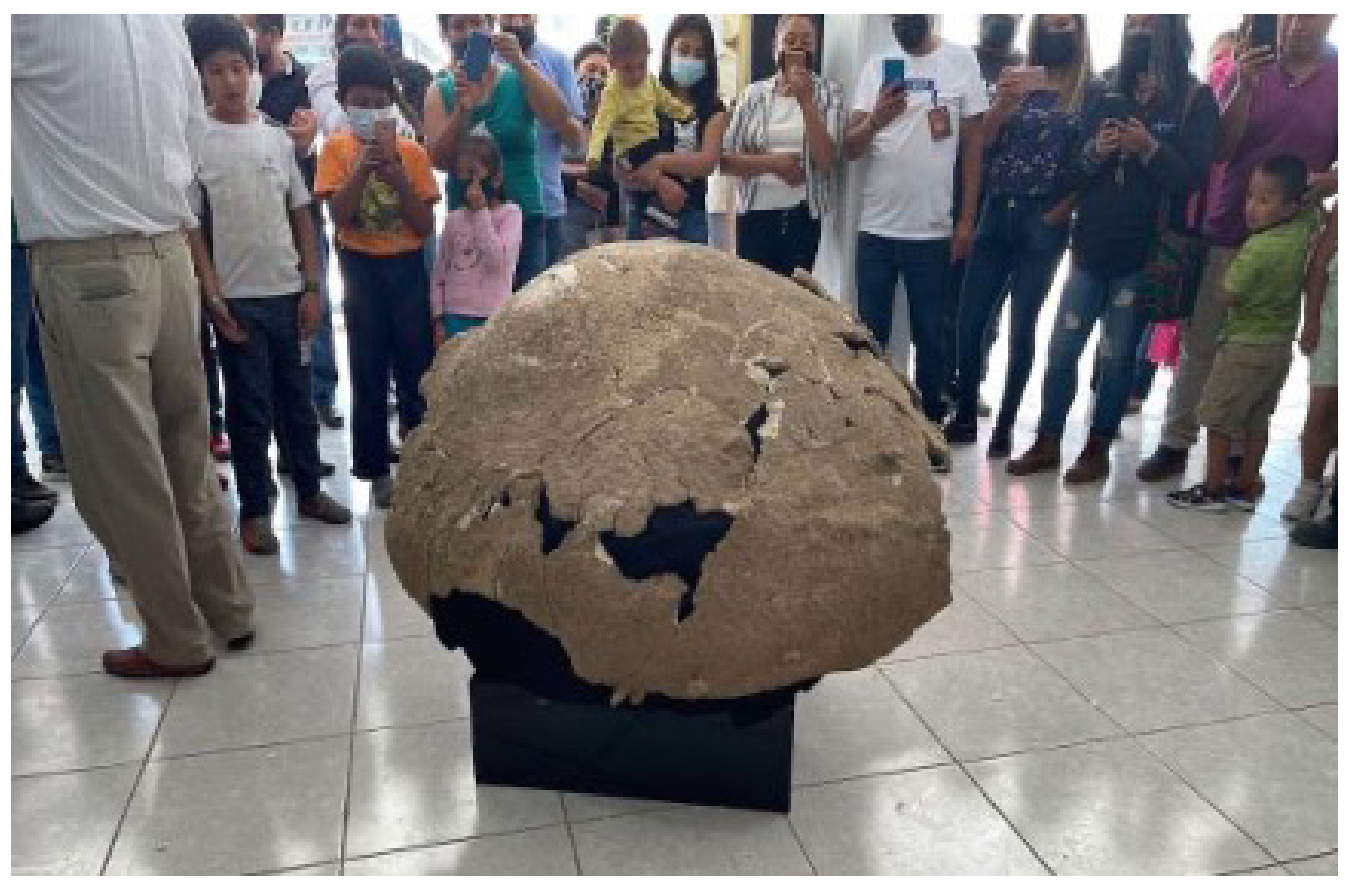

Fig. 5: Return of fossil material to the Analco neighborhood, Puebla, by the National Institute of Anthropology and History. Photograph from the La Jornada de Oriente newspaper. 


\section{s12 :: AP Journal v.11 :: SHORT ARTICLE}

On this subject, Iván Alarcón Durán, a paleontologist from the National Institute of Anthropology and History, notes that the return of this fossil "is really iconic", as it helps put an end to the idea that the National Institute of Anthropology and History "owns" heritage, when in reality it is the institution that protects, studies and displays this rich heritage. (Photograph 5)

He notes that while it was kept at the National Institute of Anthropology and History annex of Puebla, a local association conducted a series of administrative and operational tasks, until it became a contributing organization, which allowed it to be trusted with the artefact, and to subsequently display it in a space made available by the community.

Likewise, it demonstrates the paleontological wealth of the Valsequillo area as, from the 1960s onward, important megafauna discoveries numbering at least 15 animal species have been made in its ancient wetlands: from carnivores like the Pleistocene wolf and the sabre-toothed tiger, to the large proboscidean herbivores like the mammoth, gomphothere and mastodon, making it an area of great biological diversity (La Jornada 2020).

CASE 3.- The remains of the Red Queen return to Palenque.

2020: The skeleton of the Mayan sovereign was returned to Palenque, Chiapas, after 18 years of physical anthropological study. It was discovered in 1994 and, according to the latest results, the remains may belong to the wife of Mayan ruler Pakal, and not to his mother as previously believed. After extensive study in a laboratory in Mexico City, the bone remains of the Red Queen were returned to the Mayan city of Palenque, Chiapas, where they were discovered in 1994.

After the completion of the skeletal analysis and the presentation of the results, made public both in various publications and a documentary, the National Institute of Anthropology and History decided that the remains should be returned to Palenque, in accordance with the policy of keeping everything that is discovered in its archeological area of origin, in order to avoid the scattering of pieces across multiple collections and museums, declared archeologist Emiliano Gallaga, director of the National Institute of Anthropology and History annex of Chiapas. (INAH 2020b).

Based on what has been presented and discussed above, we believe that a federal program of strategic and organized devolutions is possible, a program that would take into account the cultural rights of the communities as stated in Articles 2 and 4 of the Constitution and that would become a symbol of a new era in the relationship between the National Institute of Anthropology and History and civil society, pushing for the creation of clear mechanisms of co-participation and co-responsibility. 
Above all, however, it is now necessary for us specialists in anthropology, ethnology and museography to discuss, imagine and implement new strategies to include ethnographic perspectives in current exhibitions and, if need be, to also incorporate an ethnohistoric perspective.

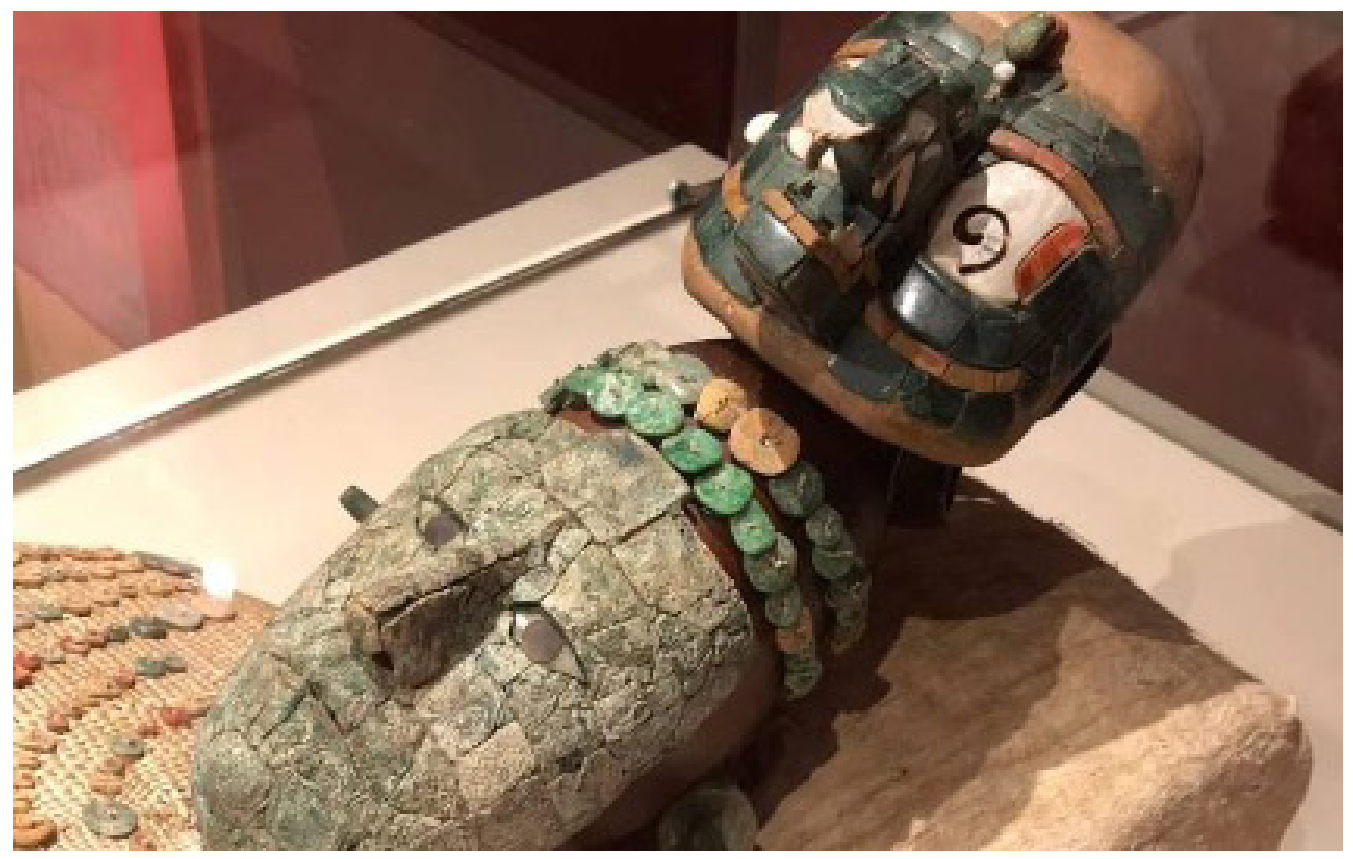

Fig. 6: The remains of the Red Queen are returned to Palenque. Photograph from the official website INAH.gob.

\section{References}

Alsina, J. 1991. Teoría literaria griega. Madrid, Gredos.

Delgado, J. 2022. The second dispossession. AP: Online Journal in Public Archaeology 12. Forthcoming.

Fujigaki, A. 2015. La disolución de la muerte y el sacrificio. Contrastes de las máquinas de transformaciones y mediaciones del rarámuri y los mexicas. Mexico, Universidad Nacional Autónoma de México. Unpublished PhD thesis.

Granados ,B. 2019. Juego de aire: relatos, mitos e iconografía de un ritual curativo en Tlayacapan Morelos, México. Revista de Literaturas Populares 9(2): 388407.

Hamilakis, Y. 2015. Arqueología y los sentidos: experiencia, memoria y afecto. Madrid, JAS Arqueología Editorial. 


\section{s14 :: AP Journal v.11 :: SHORT ARTICLE}

López L. et al. 2004. La destrucción del cuerpo. El cautivo de mármol de Teotihuacan. Revista de Arqueología Mexicana 65: 54-59

Neurath,J. 2020. Someter a los dioses, dudar de las imágenes. Enfoques relacionales en el estudio del arte ritual amerindio. Series: Arte, estética e imagen. Buenos Aires, Sb. Buenos Aires.

Eliade, M. 2019. Tratado de historia de las religiones. Morfología y dialéctica de lo sagrado. Madrid, Ediciones Cristiandad.

Preuss,T. 1998. Fiestas, literatura y magia en el Nayarit. Ensayos sobre Coras, huicholes y mexicaneros. México, Centro Francés de Estudios Mesoamericanos y Centroamericanos, Instituto Nacional Indigenista.

Trejo, L. 2015 Sonata ritual. Cuerpo, cosmos y envidia en la Huasteca meridional. Colección Etnografía de los pueblos indígenas de México. Mexico, Instituto Nacional de Antropología e Historia.

Von Winning. H. 1987. La iconografía de Teotihuacan, sus dioses y sus símbolos. Tomo I. México, Universidad Nacional Autónoma de México.

\section{Documents from the Internet}

Cárdenas Blanca, YouTube video (03/05/2021) presenting the book: Someter a los dioses dudar de las imágenes. https://www.youtube.com/watch? $v=2 \mathrm{C}$ OjeBo52ok

INAH 2020a. El INAH regresa piezas prehispánicas originales al fondo del Lago del Nevado de Toluca. (https://inah.gob.mx/boletines/9024-crean-en-el-nevado-de-toluca-el-primer-archivo-arqueologico-in-situ-para-bienes-culturales-sumergidos)

INAH 2020b. Restos de la Reina Roja retornan a Palenque. https://www.inah. gob.mx/boletines/1150-restos-de-la-reina-roja-retornan-a-palenque

La Jornada 2020. Material fósil de un Gliptodonte regresa a su lugar de origen en Puebla. https://www.lajornadadeoriente.com.mx/puebla/restos-fosiles-gliptodonte-murep/ 